\title{
Express dispatches
}

\section{ビーナス・エクスプレスからの第一報}

Andrew p. Ingersoll

ビーナス・エクスプレス・ミッションから、地球の姉妹惑星である金星の過酷な大気に関する 最初の報告が届けられた。我々は、金星の大気が地球の穏やかな大気とまったく違ったものに なった原因の解明に向かって、また一歩前進した。

Nature Vol.450 (617-618)/29 November 2007

金星は、距離だけでなく、質量、半径、密度、化学組 成においても、地球に最も近い惑星である（図 1)。し かしながら、地球が温和な気候に恵まれて生命をはぐく んできたのに対して、金星は地獄のような場所になって いる。金星の表面は高温で乾燥している。大気圧は極 端に高く、その主成分は二酸化炭素で、硫酸の雲が立 ち込めている。金星はなぜ、こんな状態になってしまっ たのだろうか?

欧州宇宙機関（ESA）のビーナス・エクスプレス探 查機は、この疑問に関連したいくつかの大きな問題を 解くために、2005 年 11 月に打ち上げられた。金星 の水はどこにあるのだろうか？ 金星にはどんな歴史が あるのだろうか? 金星の気象はどんな感じなのだろう か? 地球の気象とは違うのだろうか? 金星の大気 の組成を詳しく知ることができたら、その進化について どんなことがわかるのだろうか?今週号には、ビーナス・ エクスプレスからの第一報が 8 本の論文として掲載さ れている ${ }^{1-8}$ 。

まずは金星の水の問題について説明しょう。地球上 では、水は最も大量に存在する揮発性化合物であり、 海には大気中の 300 倍の重さの水がある。これに対し て金星では、水は大気中の水蒸気か硫酸の雲に溶けた 形で微量に存在しているだけであり、約 200ppm にし かならない。金星には海がない。金星の表面は約 $730 \mathrm{~K}$ $\left(457^{\circ} \mathrm{C}\right)$ という高温なので、たとえ水が大量にあった としても、液体として存在することはできないのである。 水以外の重要な物質としては窒素と二酸化炭素の 2 つ があり、地球にも金星にもほぼ同じ量だけ存在している。 ただし、二酸化炭素が存在している場所は異なってい る。金星では、二酸化炭素は重い大気の $96.5 \%$ を占 めていて、金星表面の気圧は地球の 92 倍にもなる。
地球では、海水中に溶け込んでいた二酸化炭素が沈殿 し、大量の石灰岩として存在している。

金星と地球は多くの点で似通っているため、両者は 同じようにして始まったと考えられる。かつては金星に も海ができるほどの水があつたにちがいないが、なんら かの機構により、その水は失われてしまった。水蒸気は 熱をため込む温室効果ガスであり、大気中の水蒸気の 量は、海から蒸発する水の量によりコントロールされて いる。地球が太陽に接近するようなことがあれば、海の 温度が上昇し、より多くの水が蒸発し、さらに温度が上 昇するだろう。ある点に達すると、温室効果はコントロー

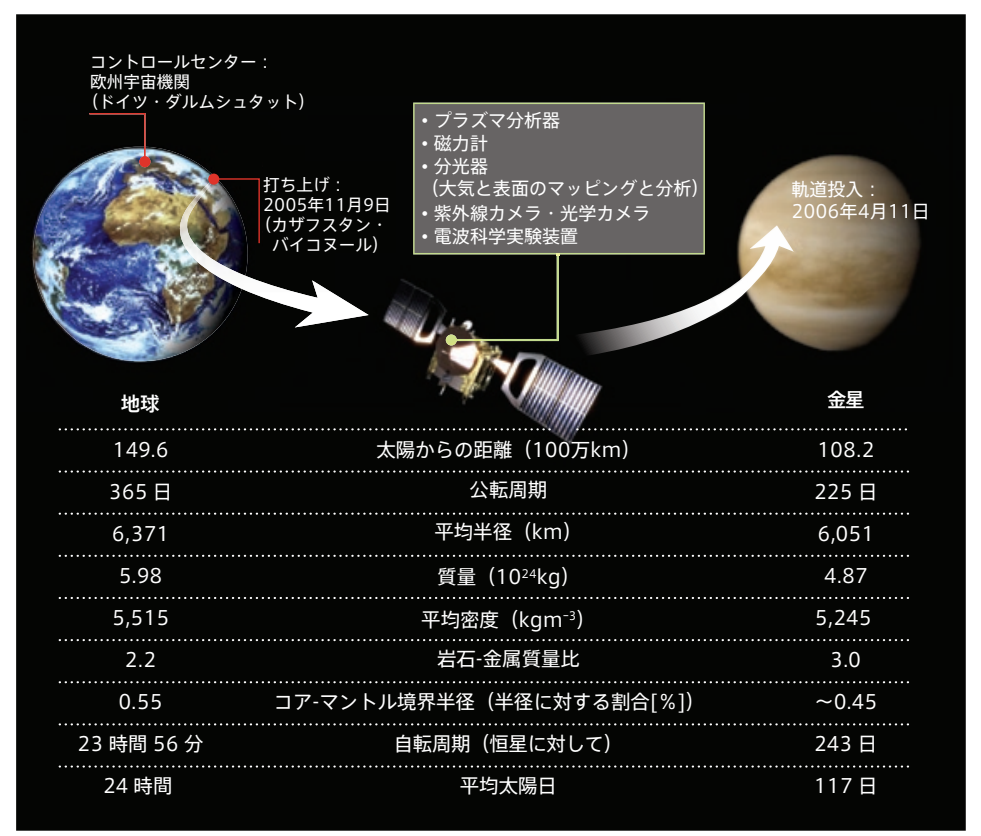

図 1 金星への旅 : 欧州宇宙機関のビーナス・エクスプレス・ミッションに関する基本 的なデータと数字 


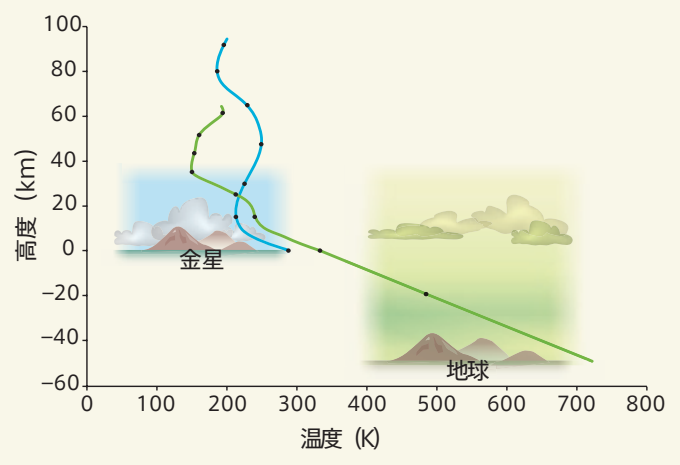

図 2 大気の海。金星の大気は非常に重く、96.5\% の二酸 化炭素と $3.5 \%$ の窒素からなっている。地球を包む穏やか な大気は、およそ $79 \%$ の窒素、 $20 \%$ の酸素、 $1 \%$ のアル ゴンからなり (乾燥空気)、二酸化炭素をはじめとする多く

ル不能になり、海は沸騰して干上がり、水は大気中に しか存在できないようになる 9

金星では、まさにこうしたことが起きた可能性がある。 金星は、現在と同じ軌道で、水蒸気からなる重い大気 をもった惑星として誕生したが、この水蒸気は日光によ り水素と酸素に分解されてしまった。軽い水素は宇宙 空間に逃げていったが、重い酸素は大気中にとどまり、 地款を酸化させて、高温で乾燥した表面を作った。通 常の水素は、その重い同位元素である重水素よりも急 速に失わ水る。実際、金星では水素に対する重水素の 存在比が地球の $100 \sim 150$ 倍も高く、莫大な量の水 が失われたことの証拠になっている。この比が最初に測 定されたのは 1978 年のことであり ${ }^{10} 、$ NASA が打ち 上げたパイオニア探査機に搭載された質量分析計の試 料導入部に詰まった硫酸の液滴から測定された。今回、 ビーナス・エクスプレスに搭載された装置は、より正確 な測定により、この高い值を確認した ${ }^{1}$ 。

今日働いていると考えられる散逸機構には、おそらく 太陽風が関係している。太陽風とは、太陽から放射さ れている荷電粒子の流れであり、これが金星の大気か ら原子やイオンを剥ぎ取っていると考元られている。し かし、その詳細については矛盾した報告がある。金星 には内部磁場がほとんどないため、太陽風は金星の大 気中で発生する磁場によってその向きを変えられる。と ころがここで、ビーナス・エクスプレスの磁力計を使っ た測定では、太陽風は大気中に侵入しておらず、その 進化に影響を及ぼすことはできないという結果になった のに対して 2 、同ミッションのプラズマ分析器を使った 測定では、正に荷電した水素イオンと酸素イオンが中性
の種類の微量ガスも含まれている(湿った空気には数％の 水蒸気が含まれている)。このグラフは、地球と金星の大気 の垂直構造を比較したものである (地球は青い線、金星は 緑色の線)。温度プロフィールにおける高度は、気圧が地球 の海面での気圧（1 気圧）に等しくなる高さをゼロとしてあ る。また、温度プロフィール上の黒い点は、気圧が 10 倍 になったり、10 分の 1 になったりするところを示している。 金星の低層大気は 1 気圧の高さから $50 \mathrm{~km}$ 近く下まで広 がっており、表面気圧は 92 気圧に達している。また、地球 の平均表面温度が $288 \mathrm{~K}\left(15^{\circ} \mathrm{C}\right)$ 前後であるのに対して、 金星の平均表面温度は 730 Kである。1 気圧の高さに対し ては、どちらの大気中の雲も(地球の雲は水から、金星の 雲は硫酸からできているという違いはあるが）同程度の高 度幅を占めており、金星の低層大気は相対的に雲が少ない。 最も高い山は、金星では平均表面高度よりも $12 \mathrm{~km}$ 高く、 地球では海报 $9 \mathrm{~km}$ である。

の原子よりも高い割合で金星の軌道上に散逸していると いう結果になったのである ${ }^{3}$ 。正味の結果として、水素 と酸素は水分子中と同じ $2: 1$ の比率で失わ机ている ${ }^{3}$ 。 絶対比は、まだ測定されていない。金星の歴史という 観点からは、この惑星に今日よりもはるかに大量の水が 存在していた時代には、まったく異なる散逸機構があっ たと考えられる。

金星に残った二酸化炭素を主成分とする大気がもた らす過酷な気象は、いくつかの点で地球とは対照的で ある。金星の大気は重いため、地球の大気よりも効率 よく熱を蓄積し、分配するはずである。ゅえに、金星の 大気の温度差は、地球の大気よりもはるかに小さくなけ ればならない。パイオニア探査機からは、この考察を 裏づける結果が得られた ${ }^{11}$ 。今回は、ビーナス・エク スプレスの電波掩蔽（えんぺい）プログラムが、さらな る検証を行った。これは、探查機から金星の大気をか すめるような電波信号を出して、その温度を測定しよう という実験である。実験の結果は、金星の高度 55 $60 \mathrm{~km}$ の雲の中では昼と夜で $30 \sim 40 \mathrm{~K}$ も大きな温 度差が生じているという驚くべきものになった ${ }^{4}$ (図 2)。 太陽光を蓄積した熱だけでは、日中にここまで温度を上 げることはできない。巨大な下降気流が圧縮によって 空気を加熱している可能性もあるが、それは地球上で 見られるいかなる大規模下降気流よりも速くなければな らない。このほかに、大気中の雲とガスが部分的に電 波信号を吸収し、計算された温度に誤差を生じさせた 可能性も考元られる 4 。

金星の大気中を高くのぼれば、風速は大きくなり、 昼夜の温度差は小さくなる。風速は固体惑星に対して 
測定される。金星の自転速度は遅く、金星が恒星に対 して 1 回転するには 243 地球日かかり、金星の表面か ら見た太陽は 117 地球日ごとに昇ったり沈んだりしてい る(金星の太陽日がかなり短いのは、金星は太陽系で 唯一、公転運動とは逆の向きにゆっくりと自転している からである。金星がなぜこのような状態になったのか、 なぜそのままなのかは、まだ明らかになっていない 12 。 ひょつとすると、太陽が重い大気中に引き起こす潮汐が、 これに関係しているのかもしれない)。

金星の雲は最高で高度 $70 \mathrm{~km}$ 近くに達し、そこでの 風速は秒速 $100 \mathrm{~m}$ (時速 $360 \mathrm{~km}$ ) 近くになる。これは、 地球の大気中に発生するハリケーンの風力の 3 倍、航 空機の速度を時速 $11 \mathrm{~km}$ 分も速くしたり遅くしたりする ジェット気流の速度の 2.5 倍に相当する。ビーナス・エ クスプレスは、金星の雲を追跡することにより、これら の強風を確認した。金星には紫外線を吸収する未知の 機構があり、日によって激しく変動しているが、これを 利用して雲の動きを観測したのである ${ }^{5}$

金星が地球やその他の惑星と共有している特徵の 1 つに、極付近の広い領域に見られる極渦とよばれる大 気の循環がある。地球の極渦は、極付近の低温の空 気を核として、それぞれの半球の冬に出現する。これ に対して金星の極渦には低温の環があり ${ }^{4,6}$ 、その内部 には、周囲よりも温度が約 $10 \mathrm{~K}$ 高い、双極子の形をし た奇妙な特徵がある。この暖かい特徵も、太陽光によ る加熱だけでは説明することができない。その成因とし ては、強い下降気流による圧縮効果が考元られる。双 極子の形をした特徵は、低緯度で暖められた空気が上 昇し、上空を極地方まで移動し、そこで泠却されて下 降し、地表付近を低緯度まで戻っていく「ハドレー循 環」が拡大したものなのかもしれない。金星では、高 度 $65 \mathrm{~km}$ 以上の高さでは、赤道は極付近よりも低温で ある（参考文献 4)。ハドレー循環がこのような状態を 保っているしくみはまだ解明されていない ${ }^{13}$ 。

金星では、固体惑星が非常にゆっくり自転している ため、大気は独自に回転している。大気の回転方向は 惑星の自転方向と同じであり、公転運動とは逆の向き に回転している。高度が上がり、大気が薄くなるにつ れて太陽からの影響が大きくなるため、より少ないエネ ルギーを吸収して、より大きな温度変化を生じるように なる。高度 $90 \mathrm{~km}$ 以上では太陽からの影響が支配的 になり、自転軸の周りを回転していた大気は、昼側か ら夜側へと流孔るようになる。昼側から夜側への空気 の流れは、昼側で生成して夜側へと運ばれる一酸化窒 素、一酸化炭素、酸素などの化合物や、昼側で破壊 されて夜側から別の化学反応の副産物として供給され
るフッ化水素や塩化水素などの化合物の測定によって 裏づけられている ${ }^{1,7}$

地球と金星の大気の比較に関する興味深い現象とし て、最後に雷について説明したい。金星の雲は地球の スモッグのようなものであるため、雷が発生するはずが ない。実際、金星の昼側でも夜側でも、はっきりした 稲妻が確認されたことはない。しかし、ビーナス・エク スプレスはホイッスラーを検出した ${ }^{8}$ 。ホイッスラーとは、 1 秒足らずの間だけ持続する低周波の電磁波であり、 放電により生じると考元られている。金星の昼側では対

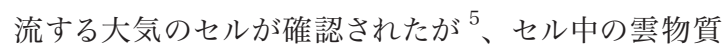
の量は、地球で雷が起こる場合の 100 分の 1 にも満た ない。これは、地球上では雲を带電させるには不十分 な量である。

このように、金星の雷をめぐる証拠には矛盾がある。 雷が存在しているなら驚くべきことだが、我々はまだ、 惑星の大気中で電気を発生させるすべての方法を検討 してみたわけではないのかもしれない。地球上での経験 にもとづく我々の直観が外れることは、これまでに何度 もあったのだから。

ビーナス・エクスプレスの燃料は 2013 年までもつ。 ミッション・コントローラーがこの探査機の能力を把握 してくるにつれて、観測シークエンスはより野心的なも のになり、金星に関する我々の知識も増大するだろう。 2011 年には、日本の金星気象衛星プラネット Cも金 星にやってくることになっている。将来の金星ミッション としては、バルーンを使って風速を測定したり、微量 ガスやその同位体を採取したり、灼熱の惑星表面から 岩石をつか夕取って涼しい高度まてもっていき、そこで 分析を行ったりすることが考えられている。いつの日か、 地球の気象プロセスを調べるように金星の気候を研究 できるようになったら、我々は気候全般を理解できるよ うになるのかもしれない。

Andrew P. Ingersoll、カリフォルニア工科大学（米)

1. Bertaux, J.-L. et al. Nature $450,646.649$ (2007).

2. Zhang, T. L. et al. Nature $450,654.656$ (2007).

3. Barabash, S. et al. Nature 450,650.653 (2007).

4. Patzold, M. et al. Nature 450, 657.660 (2007).

5. Markiewicz, W. J. et al. Nature 450, 633.636 (2007).

6. Piccioni, G. et al. Nature 450, 637.640 (2007).

7. Drossart, P. et al. Nature $450,641.645$ (2007)

8. Russell, C. T. et al. Nature 450, 661.662 (2007).

9. Ingersoll, A. P. J. Atmos. Sci. 26, 1191.1198 (1969).

10. Donahue, T. M., Hoffman, J. H., Hodges, R. R. \& Watson, A. J. Science 216 630.633 (1982).

11. Seiff, A. et al. J. Geophys. Res. 85, 7903.7933 (1980).

12. Yoder, C. F. in Venus II. Geology, Geophysics, Atmosphere, and Solar Wind Environment (eds Bougher, S. W. et al.) 1087.1124 (Univ. Arizona Press, Tucson, 1997).

13. Gierasch, P. J. et al. in Venus II. Geology, Geophysics, Atmosphere, and Solar Wind Environment (eds Bougher, S. W. et al.) 459.500 (Univ. Arizona Press, Tucson, 1997). 